\title{
Updates on the coronavirus disease 2019 vaccine and consideration in children
}

Hyun Mi Kang, MD¹, Eun Hwa Choi, MD, PhD², Yae-Jean Kim, MD, PhD ${ }^{3,4}$

${ }^{1}$ Department of Pediatrics, College of Medicine, The Catholic University of Korea, Seoul, Korea; ${ }^{2}$ Department of Pediatrics, Seoul National University College of Medicine, Seoul, Korea; ${ }^{3}$ Department of Pediatrics, Samsung Medical Center, Sungkyunkwan University School of Medicine, Seoul, Korea; ${ }^{4}$ Samsung Advanced Institute for Health Sciences and Technology (SAIHST), Seoul, Korea

Humanity has been suffering from the global severe acute respiratory syndrome coronavirus 2 pandemic that began late in 2019. In 2020, for the first time in history, new vaccine platforms - including mRNA vaccines and viral vector-based DNA vaccines - have been given emergency use authorization, leading to mass vaccinations. The purpose of this article is to review the currently most widely used coronavirus disease 2019 vaccines, investigate their immunogenicity and efficacy data, and analyze the vaccine safety profiles that have been published, to date.

Key words: COVID-19, Immunogenicity, Safety, SARSCoV-2, Vaccines

\footnotetext{
Key message

- The number of coronavirus disease 2019 cases has exponentially increased worldwide, and children $\leq 19$ years old account for $11.0 \%$ of all confirmed cases.

- mRNA vaccines, BNT162b2 and mRNA-1273, and adenoviral vector vaccines, AZD1222 and Ad26.COV2.S, authorized for emergency use in the Emergency Use Listing of the World Health Organization are reviewed.

- Clinical trials of these vaccines have shown that they are safe and serious adverse reactions are rarely observed.
}

\section{Introduction}

As the number of coronavirus disease 2019 (COVID-19) cases caused by the severe acute respiratory syndrome coronavirus 2 (SARS-CoV-2) has exponentially increased worldwide, a global pandemic was declared on March 11, 2020. As of May 20, 2021, the Korea Centers for Disease Control and Prevention reported 134,117 cumulative cases of COVID-19 and 1,916 resulting deaths. Among these cases, a total of 15,449 children and adolescents 19 years old and below were confirmed with COVID-19, accounting for $11.5 \%$ of all confirmed cases.
In outbreaks of infectious disease pandemics, in order to decrease further transmission, several measures need to be enforced. First, contact with the virus must be reduced, and this can be achieved through social distancing. Second, the transmissibility of the virus needs to be decreased by wearing masks and practicing hand-hygiene. Third, the transmission period of the virus needs to be shortened, by isolating symptomatic individuals and tracing and quarantining their contacts. Finally, the number of susceptible persons within a population needs to be decreased by vaccinations. ${ }^{1-5)}$

In South Korea, the first 3 measures were implemented in the early days of the COVID-19 pandemic. However, the last step could not be implemented until a safe and effective vaccine was developed to prevent COVID-19 infections. As of March 15, 2021, about one year after the global pandemic was declared, 4 different vaccines were authorized for emergency use in the Emergency Use Listing (EUL) of the World Health Organization (WHO). Seven vaccines have been authorized for emergency use in several countries, and 81 vaccines are currently in clinical development.6)

This article will review the mechanism of the COVID-19 vaccines authorized for emergency use to date, summarize the data of clinical trials of the vaccines, and report the safety and efficacy data of the vaccines. In addition, this review will cover considerations for the use of COVID-19 vaccines in children and adolescents.

\section{Structure of SARS-CoV-2}

SARS-CoV-2 is a bidirectional single-stranded RNA virus with a large ( $\sim 100 \mathrm{~nm}$ in diameter) envelope, containing genes for structural and non-structural proteins. ${ }^{7,8)}$ The spike protein, a structurally glycosylated protein located on the outer surface of the virus, binds to angiotensin-converting enzyme 2 receptors expressed on host cells mediating viral cell entry (Fig. 1). ${ }^{9-11)}$ This spike protein has become a key target for vaccine and

\footnotetext{
Corresponding author: Yae-Jean Kim, MD, PhD. Department of Pediatrics, Samsung Medical Center, Sungkyunkwan University School of Medicine, 81 Irwon-ro, Gangnamgu, Seoul 06351, Korea 


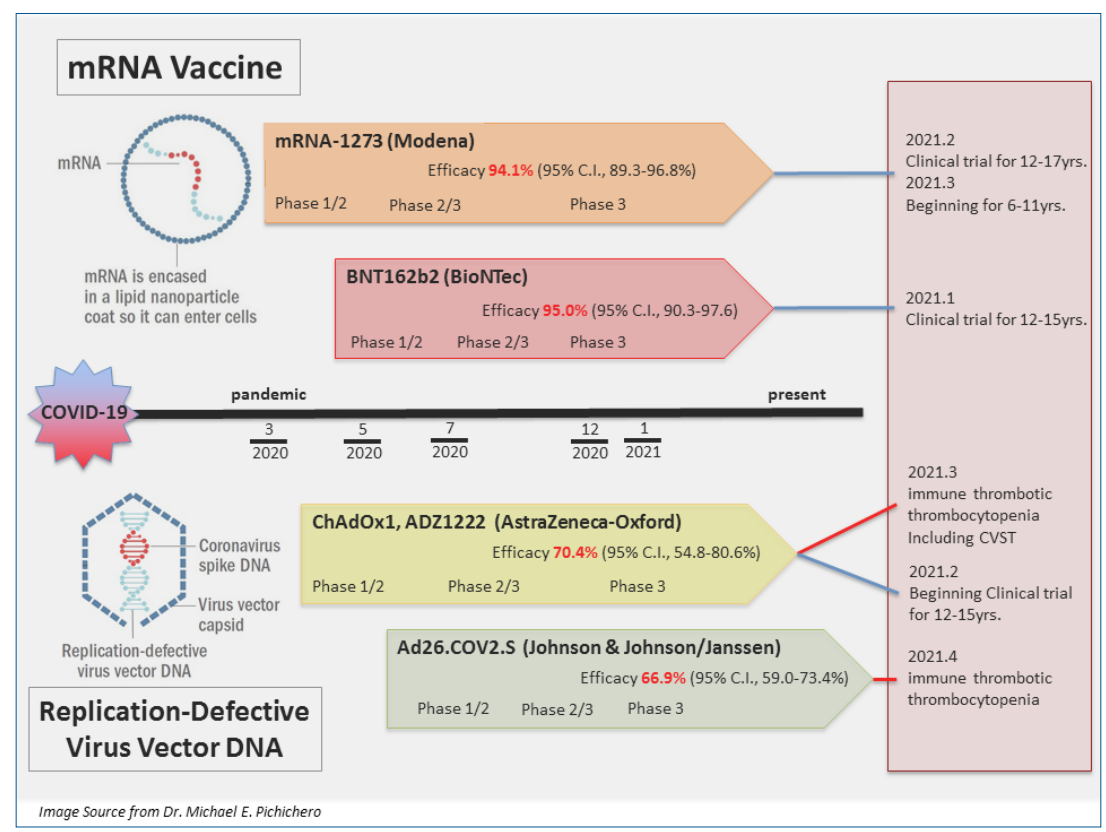

Graphic abstract. Summary of the 4 vaccines that have been authorized for emergency use in the Emergency Use Listing of the World Health Organization.

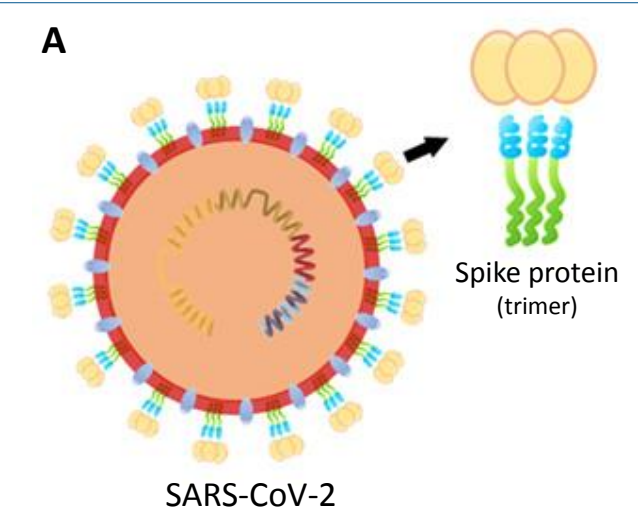

B

Fig. 1. Severe acute respiratory syndrome coronavirus-2 (SARS-CoV-2)'s spike protein structure and binding with the angiotensin-converting enzyme 2 (ACE2) receptor. (A) The structural glycosylated spike proteins located on the surface of the viral envelope (B) bind to the host cell receptor angiotensin-converting enzyme 2 (ACE2) and mediate viral cell entry.

therapeutics for its important role in SARS-CoV-2 infection. ${ }^{11,12)}$ Most vaccines that are currently authorized for use target the spike protein to elicit an antibody response. ${ }^{13-16)}$

\section{COVID-19 vaccine platform}

There are 10 vaccine platforms for 81 vaccines that are currently in clinical development. Among them, the protein subunit platform accounts for $33 \%$ of the vaccines $(n=27)$, followed by nonreplicating viral vector $(15 \%, n=12)$, DNA $(14 \%, n=$ $11)$, inactivated virus $(12 \%, n=10)$, and RNA $(12 \%, n=10)$ platforms. ${ }^{6}$ ) Two of the 4 vaccines (BNT162b2 [Pfizer-BioNTech, New York, NY, USA] and mRNA-1273 [Moderna, Cambridge, MA, USA]) authorized for emergency use in the WHO EUL are RNA vaccines, while the other 2 (AZD1222 [AstraZeneca, Cambridge, UK] and Ad26.COV2.S [Janssen, Beerse, Belgium]) are non-self-replicating virus vector platform vaccines ${ }^{17,18)}$

\section{Mechanism of action of RNA and viral vector vaccines}

\section{1. mRNA vaccine}

RNA vaccine was the first type of vaccine authorized for emergent use to prevent COVID-19. BNT162b2 and mRNA1273 have a similar mechanism of action. RNA vaccines use messenger RNA (mRNA) that encodes the $S$ gene for the spike protein. ${ }^{11,19,20)}$ However, mRNA molecules are fragile, and are degraded by biological enzymes when they are injected directly into the human body. Therefore, mRNA molecules contained in the vaccines are enclosed in lipid membranes made of lipid nanoparticles (Fig. 2, right). ${ }^{21)}$

Once the vaccine is administered, the lipid nanoparticles bind 


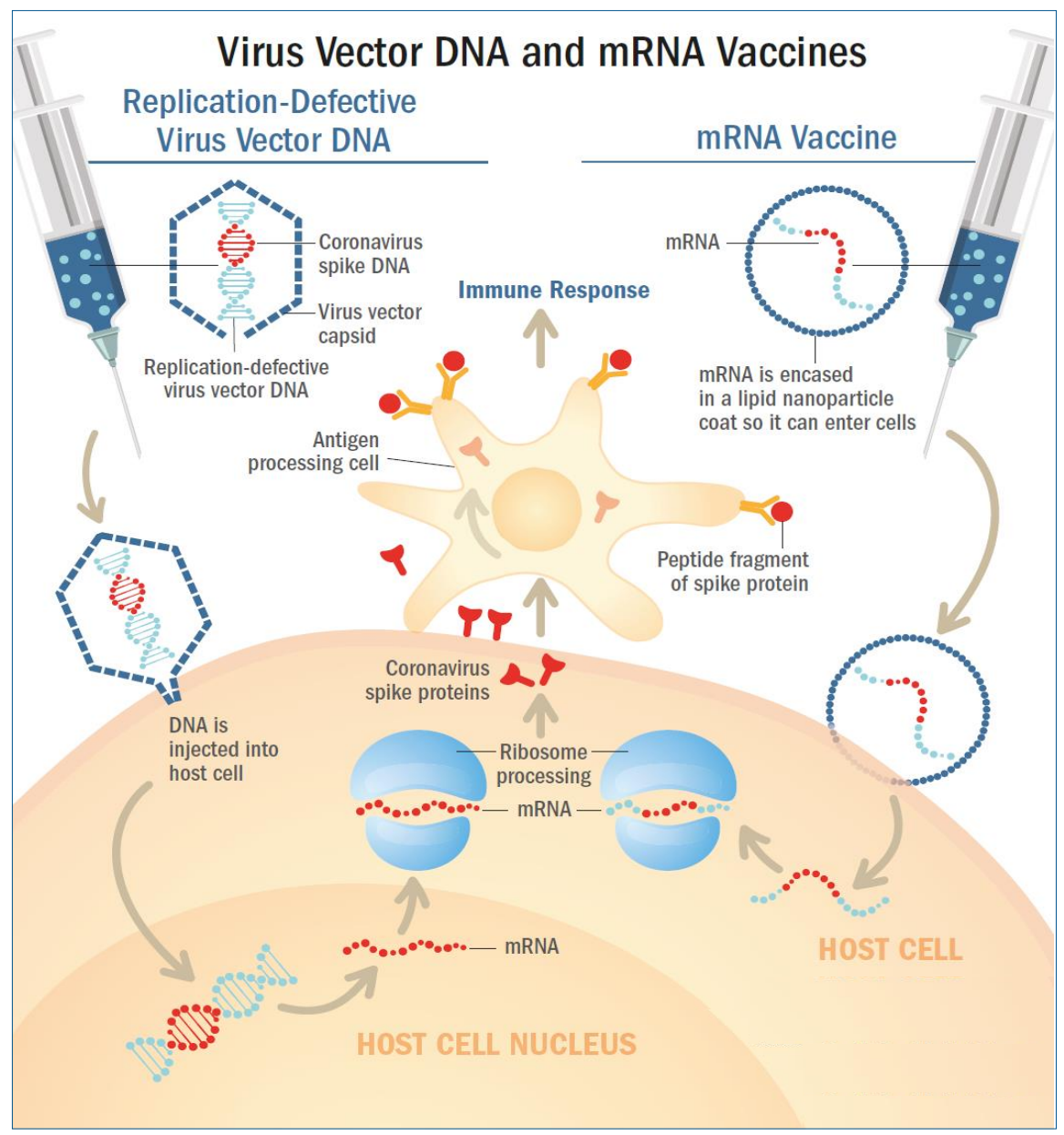

Fig. 2. Nonreplicating viral vector vaccine and mRNA platform vaccine. (Left) Adenovirus vectors carry the severe acute respiratory syndrome coronavirus-2 (SARS-CoV-2) spike protein gene, S gene. Upon administration, the virus binds and enters human cells. The DNA of the SARS-CoV-2 $\mathrm{S}$ gene is injected into the cell nucleus, and is then transcribed into $\mathrm{mRNA}$, which is then released into the cell's cytoplasm. The cell's ribosomes and tRNA (transfer RNA) translate the mRNA and build spike proteins. (Right) The RNA vaccines use messenger RNA (mRNA) that encodes the spike protein's genetic material, which are contained within oily shells made of lipid nanoparticles. After injection, the vaccine particles fuse to human cells and endocytosis occurs, releasing mRNA into the cell's cytoplasm. The cell's ribosomes and tRNA translate the mRNA and build spike proteins. (Common) The cells then present the spike proteins on their surfaces, which is then recognized by antigen presenting cells (APC) such as macrophages or dendritic cells. These APCs identify the spike protein antigens and activate an immune response, causing helper (CD4+) T cells to recruit B cells that create SARS-CoV-2 neutralizing antibodies, and cytotoxic (CD8+) T cells to produce and release cytotoxins. Memory $B$ and T cells then remain in the body to provide immunological memory. Reproduced by permission from MD Edge, Understanding messenger RNA and other SARS-CoV-2 vaccines (https://www.mdedge.com/hematology-oncology/article/233491/coronavirus-updates/ understanding-messenger-rna-and-other-sars, (Publish date: December 14, 2020). ${ }^{21}$

to human cells, and mRNA is released into the cytoplasm of the cells through endocytosis. Cellular ribosomes and transfer RNA (tRNA) translate the codons of mRNA to produce spike proteins. The mRNAs are then destroyed by host cells and leave no permanent trace. The host cells present the spike proteins on their surface, which are recognized by antigen presenting cells (APC) such as macrophages and dendritic cells. These APCs absorb the spike protein antigen and break them down into peptides to present them on their surface. These peptides are then recognized by helper $(\mathrm{CD} 4+) \mathrm{T}$ cells to elicit an immune response. This leads to the recruitment of cytotoxic $(\mathrm{CD} 8+) \mathrm{T}$ cells that produce cytotoxins which destroy virus-infected cells (cell-mediated immunity), and B cells that produce antibodies which neutralize the SARS-CoV-2 (antibody-mediated immunity). Afterwards, memory $\mathrm{B}$ and $\mathrm{T}$ cells remain in the body to provide immune memory (Fig. 2, right). ${ }^{22,23)}$ Because the fragile mRNA molecules rapidly degrade at room temperature, mRNA vaccines must be stored at extremely low temperatures to maintain its stability.

\section{Viral vector vaccines}

The 2 viral vector vaccines, AZD1222 and Ad26.COV2.S, are adenovirus vector-based. AZD1222 vaccine uses replicationdeficient simian adenovirus vector ChAdOx1. ${ }^{15,24)}$ Ad26. COV2.S vaccine uses replication-incompetent human adenovirus type 26 vector (Ad26). ${ }^{16)}$ 
In both vaccines, the adenovirus vector is designed to carry the $S$ gene that encodes the spike protein. Upon administration, the virus binds to and enters human cells. The DNA of the $S$ gene reaches the nucleus and is transcribed into mRNA to be released into the cytoplasm. Cellular ribosomes and tRNAs in the cytoplasm translate the codons of the mRNA to produce spike proteins. The cells then present the spike protein on their surface, and these are recognized by APCs to activate CD4+ and $\mathrm{CD} 8+\mathrm{T}$ cell-mediated immune responses and memory (Fig. 2 , left). ${ }^{21,25,26)}$ These viral vector vaccines are recommended to be transported and stored in $2^{\circ} \mathrm{C}-8^{\circ} \mathrm{C}$, which are not as low as mRNA vaccines.

\section{COVID-19 vaccine types}

As of March 23, 2021, 4 vaccines have been authorized for use and registered on the WHO EUL: BNT162b2, mRNA1273, AZD1222, and Ad26.COV2.S. The immunogenicity and safety of the 4 vaccines were evaluated through phase $1 / 2$ clinical trials, and vaccine efficacy and adverse events were assessed in phase 3 clinical trials by comparing vaccine and control groups of participants. Based on the outcome of the phase 3 clinical trial, Ad26.COV2.S was authorized for single administration. The other 3 vaccines were approved for the administration of 2 doses (Table 1). All 4 vaccines are administered intramuscularly. The BNT162b2 vaccine has been authorized initially for ages 16 years and older and later authorized for ages 12 years old and older on May 10, 2021, whereas the mRNA-1273, AZD1222, and Ad26.COV2.S have been authorized for those over 18 years old. Prior to administration, the cold chain of the vaccines must be maintained from the manufacturing stage. As described above, mRNA vaccines (BNT162b2 and mRNA-1273) must be stored and distributed in low temperatures and cannot be stored at refrigeration temperature for long-term (Table 1).

\section{Immunogenicity and efficacy of COVID-19 vaccines}

In January 2020, BioNTech initiated the development of the mRNA of SARS-CoV-2 spike protein. In March, a joint study with Pfizer was initiated, and phase $1 / 2$ clinical studies were successfully started in April and May. The following 2 mRNAs

Table 1. Technical summary of the current coronavirus disease 2019 vaccines

\begin{tabular}{|c|c|c|c|c|}
\hline & \multicolumn{4}{|c|}{ Vaccine name } \\
\hline & BNT162b2 & mRNA-1273 & AZD1222 & Ad26.COV2.S \\
\hline Manufacturer & Pfizer \& BioNTech & Moderna & AstraZeneca & Janssen (J\&J) \\
\hline Platform & mRNA & mRNA & $\begin{array}{l}\text { Viral vector (recombinant } \\
\text { adenovirus, ChAdOx1) }\end{array}$ & $\begin{array}{l}\text { Viral vector (human adenovirus } \\
\text { serotype } 26, \text { Ad26) }\end{array}$ \\
\hline $\begin{array}{l}\text { No. of doses (schedule) } \\
\text { - Phase } 3 \\
\text { - KDCA guidance }\end{array}$ & $\begin{array}{l}\text { 2-dose ( } 21 \text { days) } \\
\text { 2-dose ( } 21 \text { days) }\end{array}$ & 2-dose (28 day) & $\begin{array}{l}\text { 2-dose (28 day) } \\
\text { 2-dose (8-12 wk) }\end{array}$ & 1-dose \\
\hline Route & Intramuscular & Intramuscular & Intramuscular & Intramuscular \\
\hline Approved age & $\geq 12 \mathrm{yr}$ & $\geq 18 \mathrm{yr}$ & $\geq 18 \mathrm{yr}$ & $\geq 18 \mathrm{yr}$ \\
\hline \multicolumn{5}{|l|}{ Cost per dose } \\
\hline US & $\$ 19.50$ & $\$ 15.00$ & $\$ 4.00$ & $\$ 10.00$ \\
\hline EU & $\$ 14.76$ & $\$ 18.00$ & $\$ 2.19$ & $\$ 8.50$ \\
\hline Administration conditions & $2^{\circ} \mathrm{C}-25^{\circ} \mathrm{C}(6 \mathrm{hr})$ & Room temperature (6 hr) & $2^{\circ} \mathrm{C}-8^{\circ} \mathrm{C}(48 \mathrm{hr})$ & Refrigerated $\left(4^{\circ} \mathrm{C}-6^{\circ} \mathrm{C} \mathrm{hr}\right)$ \\
\hline Transport conditions & $2^{\circ} \mathrm{C}-8^{\circ} \mathrm{C}$ (31 day)a) & $2^{\circ} \mathrm{C}-8^{\circ} \mathrm{C}$ (30 day) & $2^{\circ} \mathrm{C}-8^{\circ} \mathrm{C}(6 \mathrm{mo})$ & $2^{\circ} \mathrm{C}-8^{\circ} \mathrm{C}(3 \mathrm{mo})$ \\
\hline Storage conditions & $\begin{array}{l}\left.-25^{\circ} \mathrm{C} \text { to }-15^{\circ} \mathrm{C}(2 \mathrm{wk})^{\mathrm{b}}\right) \\
-80^{\circ} \mathrm{C} \text { to }-60^{\circ} \mathrm{C}(6 \mathrm{mo})\end{array}$ & $-20^{\circ} \mathrm{C}(6 \mathrm{mo})$ & $2^{\circ} \mathrm{C}-8^{\circ} \mathrm{C}(6 \mathrm{mo})$ & $-25^{\circ} \mathrm{C}$ to $-15^{\circ} \mathrm{C}$ (24 mo) \\
\hline $\begin{array}{l}\text { Early, limited, or emergency use } \\
(\text { as of March 26, 2021) })^{c}\end{array}$ & $\begin{array}{l}\text { Australia } \\
\text { Canada } \\
\text { EU } \\
\text { Iceland } \\
\text { Israel } \\
\text { Japan } \\
\text { South Korea } \\
\text { Switzerland } \\
\text { UK } \\
\text { U.S. FDA } \\
\text { WHO } \\
\text { etc. } \\
\text { ( } \geq 41 \text { countries) }\end{array}$ & $\begin{array}{l}\text { Canada } \\
\text { EU } \\
\text { Iceland } \\
\text { Israel } \\
\text { Switzerland } \\
\text { UK } \\
\text { U.S. FDA } \\
\text { WHO } \\
\text { etc. } \\
\text { ( } \geq 12 \text { countries) }\end{array}$ & $\begin{array}{l}\text { Australia } \\
\text { Canada } \\
\text { EU } \\
\text { Iceland } \\
\text { India } \\
\text { South Korea } \\
\text { UK } \\
\text { WHO } \\
\text { etc. } \\
\text { ( } \geq 49 \text { countries) }\end{array}$ & $\begin{array}{l}\text { Canada } \\
\text { EU } \\
\text { Iceland } \\
\text { Switzerland } \\
\text { U.S. FDA } \\
\text { WHO } \\
\text { ( } \geq 8 \text { countries) }\end{array}$ \\
\hline
\end{tabular}

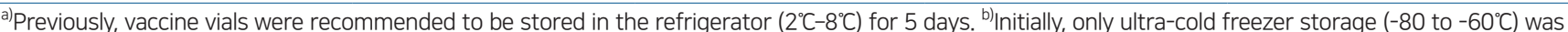
recommended. However, data showed that vaccine vials may be stored in $-25^{\circ} \mathrm{C}$ to $-15^{\circ} \mathrm{C}$ for up to 2 weeks before being stored in the refrigerator $\left(2^{\circ} \mathrm{C}-8^{\circ} \mathrm{C}\right)$ for

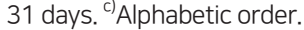

KDCA, Korea Disease Control and Prevention Agency; US, United States; EU, European Union; UK, United Kingdom; WHO, World Health Organization; FDA, U.S. Food and Drug Administration.
} 
were included in the vaccines in phase $1 / 2$ clinical studies: BNT162b1 (SARS-CoV-2 receptor-binding domain) and BNT162b2 (total length of SARS-CoV-2 spike protein). In the phase 1/2 clinical studies of 195 patients, both mRNA targets showed similar dose-dependent SARS-CoV-2 neutralizing antibody geometric mean titers (GMTs). However, the severity and incidence of adverse reactions were lower in those vaccinated with BNT162b2. Thus, BNT162b2 was selected as the candidate for phase $2 / 3$ clinical trials. ${ }^{13)}$ The phase 3 clinical study of BNT162b2 was conducted in 43,438 participants aged 16 years and older in 6 different countries including the United States, Turkey, and Germany, and the efficacy and safety of the vaccine were evaluated and compared between vaccine $(n=21,720)$ and control $(n=21,728)$ groups. After 7 days from the second dose, the number of COVID-19 confirmed cases were assessed every 21 days. A total of 8 and 162 cases of COVID-19 were reported in the vaccine and control groups, respectively, and a vaccine efficacy of 95\% (95\% credible interval, 90.3-97.6) was reported. ${ }^{27)}$ In December 2020, the emergency use of BNT162b2 vaccine was authorized in the United States (US), United Kingdom (UK), and by WHO leading to the start of mass vaccinations in the US and Europe (Table 2).

The second vaccine that gained authorization was also an mRNA vaccine, $m R N A-1273$. Its phase $1 / 2$ clinical trial began in March-April 2020 through a collaboration between Moderna and the National Institutes of Health of the US. A total of 45 participants were recruited and assigned to 3 groups with different vaccine doses $(25 \mu \mathrm{g}, 100 \mu \mathrm{g}$, or $250 \mu \mathrm{g})$ to assess the safety and immunogenicity of the vaccine. In all groups, the GMT of the dose-dependent SARS-CoV-2 neutralizing antibody was reached, and titers corresponding to $\geq 50 \%$ observed in the serum of COVID-19 confirmed patients were observed in all

Table 2. Summary of characteristics of clinical trials of coronavirus disease 2019 vaccine and efficacy data

\begin{tabular}{|c|c|c|c|c|}
\hline \multicolumn{5}{|c|}{ Vaccine name } \\
\hline & BNT162b2 ${ }^{13,27)}$ & mRNA-1273 ${ }^{14,31)}$ & AZD1222 $15,28,29)$ & Ad26.COV2. $S^{16,30)}$ \\
\hline Manufacturer & Pfizer & Moderna & AstraZeneca & Janssen (J\&J) \\
\hline \multicolumn{5}{|l|}{ Clinical trial (published data) } \\
\hline Phase 1/2 & $\begin{array}{l}\text { - Phase 1/2 (start: 2020.05) } \\
\text { BNT162b1 and BNT162b2 } \\
\text { both induced anti-SARS- } \\
\text { CoV-2 immune responses } \\
\text { - BNT162b2 had less systemic } \\
\text { reaction; therefore, was } \\
\text { selected for phase } 3 \text { clinical } \\
\text { trial }\end{array}$ & $\begin{array}{l}\text { - Phase 1/2 (start: 2020.03) } \\
\text { mRNA-1273 induced anti- } \\
\text { SARS-CoV-2 immune res- } \\
\text { ponses in all participants } \\
\text { - No trial-limiting safety con- } \\
\text { cerns }\end{array}$ & $\begin{array}{l}\text { - Phase } 1 / 2 \text { (start: } 2020.04) \\
\text { - Neutralizing Ab response: } \\
\text { After dose } 1 \text { - } 91 \% \text {, dose } 2 \\
\text { - } 100 \% \\
\text { - No serious adverse events } \\
\text { related to ChAdOx1 nCOV- } \\
19\end{array}$ & $\begin{array}{l}\text { - Phase 1/2a (start: 2020.07) } \\
\text { - Single dose seroconversion } \\
\text { for S antibodies (by ELISA): } \\
\text { Cohort 1a: } 99 \% \text {; cohort } 3 \text { : } \\
\text { 100\% }\end{array}$ \\
\hline Phase 3 & $\begin{array}{l}\text { Phase 2/3 (start: 2020.07) } \\
\text { Country: US, Argentina, Brazil, } \\
\text { South Africa, Germany, } \\
\text { Turkey } \\
\mathrm{N}=43,548 \\
\text { 21-day interval/2-dose }\end{array}$ & $\begin{array}{l}\text { Phase } 3 \text { (start 2020.07) } \\
\text { Country: US } \\
\mathrm{N}=30,420 \\
\text { 28-day interval/2-dose }\end{array}$ & $\begin{array}{l}\text { Phase 2/3 (start 2020.04) } \\
\text { Country: UK, Brazil } \\
\text { N=23,848 } \\
\text { LD/SD (UK): n=2,741; } \\
\text { SD/SD (UK): n=4,807; } \\
\text { SD/SD (Brazil): n=4088; } \\
\text { Country: UK (phase 1/2 \& } \\
\text { phase 3), Brazil (3), South } \\
\text { Africa (1/2) } \\
\text { N=17,177 } \\
\text { SD/SD: } n=14,379 \\
\text { LD/SD (UK only): } n=2,798 \\
\text { 28-day interval/2-dose }\end{array}$ & $\begin{array}{l}\text { Phase } 3 \text { ENSEMBLE (start } \\
\text { 2020.09-): } \\
\text { Country: Argentina, Brazil, } \\
\text { Chile, Colombia, Mexico, } \\
\text { Peru, South Africa, US } \\
\text { N=43,783 } \\
\text { 1-dose }\end{array}$ \\
\hline Study type & $\begin{array}{l}\text { Observer-blinded placebo- } \\
\text { controlled }\end{array}$ & $\begin{array}{l}\text { Observer-blinded placebo- } \\
\text { controlled }\end{array}$ & $\begin{array}{l}\text { Blinded, randomized, con- } \\
\text { trolled trials }\end{array}$ & $\begin{array}{l}\text { Double-blinded placebo-con- } \\
\text { trolled }\end{array}$ \\
\hline Phase 3 trial inclusion & $\begin{array}{l}\geq 16 \mathrm{yr} \\
>55 \mathrm{yr}(42.2 \%)\end{array}$ & $\begin{array}{l}\geq 18 \mathrm{yr} \\
\geq 65 \mathrm{yr}(24.8 \%)\end{array}$ & $\begin{array}{l}\geq 18 \mathrm{yr} \\
\geq 56 \mathrm{yr}(12.2 \%)\end{array}$ & $\begin{array}{l}\geq 18 \mathrm{yr} \\
\geq 65 \mathrm{yr}(19.6 \%)\end{array}$ \\
\hline Exclusion & $\begin{array}{l}\text { History of COVID-19 } \\
\text { Treatment with immunosup- } \\
\text { pressants } \\
\text { Immunocompromised }\end{array}$ & $\begin{array}{l}\text { Known history of SARS- } \\
\text { CoV-2 infection } \\
\text { Pregnant } \\
\text { Breastfeeding } \\
\text { Treatment with immunosup- } \\
\text { pressants } \\
\text { Immunocompromised }\end{array}$ & $\begin{array}{l}\text { Severe and/or uncontrolled } \\
\text { underlying disease } \\
\text { Pregnant } \\
\text { Breastfeeding }\end{array}$ & $\begin{array}{l}\text { Pregnant } \\
\text { Immunocompromised } \\
\text { Previously received a COVID- } \\
19 \text { vaccine } \\
\text { Allergies or history of anaphy- } \\
\text { laxis or other serious ad- } \\
\text { verse reaction to vaccines } \\
\text { Acute illness }\end{array}$ \\
\hline $\begin{array}{l}\text { Vaccine efficacy at pre- } \\
\text { venting COVID-19 }\end{array}$ & $\begin{array}{c}\geq 7 \text { days after } 2 \text { nd dose: } 95 \% \\
\left(95 \% \mathrm{Cl}^{*}, 90.3 \%-97.6 \%\right)\end{array}$ & $\begin{array}{l}\geq 14 \text { days after } 2 \text { nd dose (all } \\
\quad \text { symptomatic): } 94.1 \%(95 \% \\
\quad \text { Cl, } 89.3 \%-96.8 \%)\end{array}$ & $\begin{array}{l}\geq 14 \text { days after } 2 \text { nd dose (all } \\
\text { symptomatic): } 70.4 \%(95 \% \\
\text { Cl: } 54.8 \%-80.6 \%)\end{array}$ & $\begin{array}{l}\geq 14 \text { days after single dose (all } \\
\text { symptomatic): } 66.9 \%(95 \% \\
\text { Cl: } 59.1 \%-73.4 \%)\end{array}$ \\
\hline $\begin{array}{l}\text { Confirmed COVID-19 cases } \\
\text { after last vaccination } \\
\text { (endpoint) }\end{array}$ & $\begin{array}{l}\text { Vaccine group: } n=8 / 18,198 \\
\text { Placebo group: } n=162 / 18,325\end{array}$ & $\begin{array}{l}\text { Vaccine group: } 11 / 14,134 \\
\text { Placebo group: } 185 / 14,073\end{array}$ & $\begin{array}{l}\text { Vaccine group: } 30 / 5807 \\
\text { Control group }^{\text {a): }} \text { 101/5829 }\end{array}$ & $\begin{array}{l}\text { Vaccine group: } 117 / 19,630 \\
\text { Placebo group: } 351 / 19,691\end{array}$ \\
\hline
\end{tabular}

ELISA, enzyme-linked immunosorbent assay; US, United States; UK, United Kingdom; Cl, confidence interval; CI*, credible interval; LD, low dose; SD, standard dose.

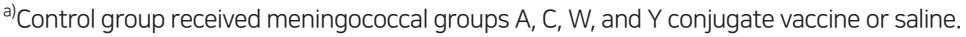


groups. However, the incidence of adverse events was higher in the $250 \mu \mathrm{g}$ group compared to other groups. Thus, $100 \mu \mathrm{g}$ was selected as the dose for phase 3 clinical trial. ${ }^{14)} \mathrm{A}$ total of 30,420 participants were recruited from 99 different institutions in the US for the phase 3 clinical trial, and the vaccine and control groups were compared in a 1:1 ratio. After 14 days from the second vaccination, newly confirmed COVID-19 cases were assessed every 28 days. A total of 11 and 185 cases of COVID-19 were observed in the vaccine and control groups, respectively, and a vaccine efficacy of $94.1 \%$ (95\% confidence interval [CI], 89.3-96.8) was reported (Table 2). ${ }^{28)}$

A group of researchers at the Oxford University began studying simian adenovirus vectors in January 2020. In April 2020, the development of a new COVID-19 vaccine was initiated in collaboration with AstraZeneca, and phase 1/2 clinical trial was initiated in the UK. A total of 1,077 healthy adults were recruited to evaluate the safety and immunogenicity of the vaccine in the ChAdOx1 $\mathrm{nCoV}-19$ vaccine group $(\mathrm{n}=543)$ and MenACWY control group ( $\mathrm{n}=534)$. Microneutralization assay $80 \%$ (MNA80) was used, and $91 \%$ and $100 \%$ neutralizing antibody reaction were observed after the first and second doses, respectively. Thus, the ChAdOx $1 \mathrm{nCoV}-19$ phase 3 clinical trials began. ${ }^{15)}$ Participants were recruited from the UK (June), Brazil (June), and the US (September), and the results of the study in the UK and Brazil were published in January 2021. In the UK phase 3 clinical trial, a low dose (LD) $\left(2.2 \times 10^{10}\right.$ viral particles) was administered accidentally for the first dose in some of the participant. Thus, those who received a $\mathrm{LD}$ of the vaccine for the first dose and a standard dose (SD) $\left(5 \times 10^{10}\right.$ viral particles) for the second dose were analyzed separately. In other vaccine groups, SD were administered for both first and second doses, as in Brazil. As a result, data of 11,636 participants in the UK ChAdOx1 nCoV-19 (ADZ1222) LD/SD $(n=2,741)$ and control $(n=1,374)$ groups, UK SD/SD $(n=2,377)$ and control $(\mathrm{n}=2,430)$ groups, and Brazil SD/SD $(\mathrm{n}=2,063)$ and control $(n=2025)$ groups were analyzed. After 14 days from the second vaccination, a total of 30 and 101 symptomatic COVID-19 cases were observed in the vaccine and control groups, respectively. The vaccine efficacy was $70.4 \%$ (95\% CI, 54.8-80.6) regardless of the dose. Assessment of the efficacy per dose showed that the vaccine efficacy was $62.1 \%(95 \% \mathrm{CI}, 41.0-75.7)$ in the SD/SD group and $90.0 \%$ (95\% CI, 67.4-97.0) in LD/SD group (Table 2). ${ }^{29)}$ Afterwards, data of 17,178 participants from South Africa (vaccine group, $\mathrm{n}=8,597$; control group, $\mathrm{n}=8,581$ ), in a phase 3 clinical trial were reported. The vaccine efficacy was $55.1 \%$ (95\% CI, 33.0-69.9) in those who received a second dose within 6 weeks after the first dose. In contrast, the vaccine efficacy was 81.3\% (95\% CI, 60.3-91.2) in those who received the second dose 12 weeks after the first dose. ${ }^{30)}$

Johnson \& Johnson (Janssen) also started developing a COVID-19 vaccine in January 2020, and a phase 1/2 clinical trial was initiated in July. A total of 805 participants were classified into 3 groups. In group 1 (18-55 years) and group 3 (over 65 years), $5 \times 10^{10}$ viral particles (LD) or $1 \times 10^{11}$ viral particles (high dose) were administered once or twice, and the safety and immunogenicity of the vaccines were compared. A single vaccination led to a neutralizing antibody response in $90 \%$ of the vaccinated participants, and the neutralizing antibody titer remained stable and high until 71 days after vaccination. ${ }^{16)}$ In this study, group 2 was evaluated for long-term immunogenicity, and this data has not been published. In the phase 3 clinical trial of the Ad26.COV2.S vaccine published on January 21, 2020, the interim data of 39,321 participants 18 years and older in countries including Brazil, the US, and South Africa were analyzed for the number of confirmed COVID-19 cases 14 days after the second dose, showing a vaccine efficacy of $66.9 \%$ (95\% CI, 59.0-73.4) (Table 2). ${ }^{31)}$

Starting the second half of 2020, various mutant strains of SARS-CoV-2 have been circulating in the UK, South Africa, and Brazil, and there have been growing concerns regarding the spread of these mutant strains worldwide. The immunogenicity and efficacy of vaccines against these mutant strains are currently being assessed. Due to the changing viral molecular dynamics, real-world data on the effects of the vaccines warrant constant update as vaccines were rolled-out in communities throughout the world.

\section{Safety of COVID-19 vaccines}

In order to contain the global COVID-19 pandemic, it is important to increase the number of people with immunity to SARS-CoV-2 within a population. Because the entire global population is a candidate for the vaccine, the safety of vaccines must be assured. Solicited adverse events, serious adverse events, and deaths during phase $1 / 2$ and 3 clinical trials of the 4 authorized vaccines have been reported, and associations of these events with the vaccines have also been thoroughly assessed (Table 3). During the clinical trials, no vaccine-related deaths were reported, and a low rate of vaccine-related adverse events were observed, suggesting that all 4 vaccines are safe (Table 3). ${ }^{27-}$ 29,32) Following the initiation of vaccinations around the world, Brighton collaboration, European Medicines Agency (EMA), the U.S. Food and Drug Administration (FDA), and the Korean Ministry of Food and Drug Safety have been and will continue to make great efforts to monitor vaccine safety and adverse reactions.

Cases of immune thrombotic thrombocytopenia were reported in March and April 2021 after vaccination with AZD1222 and Ad26.COV2.S, which are adenovirus vector vaccines. ${ }^{33-35)}$ In particular, rare cases of cerebral venous sinus thrombosis (CVST) related to vaccination have been reported. According to EMA, as of April 4, 2021, 169 cases of CVST were reported after AZD1222 vaccination in countries of the European Economic Area and the UK. ${ }^{36}$ However, the number of thromboembolism cases that occurred after AZD1222 vaccination (1 per 250,000) was not greater than the number observed in the general population (1 per 100,000), and was lower than the number of 
Table 3. Safety and reported adverse events of coronavirus disease 2019 (COVID-19) vaccines from clinical trials

\begin{tabular}{|c|c|c|c|c|}
\hline & \multicolumn{4}{|c|}{ Vaccine name } \\
\hline & BNT162b2 ${ }^{27)}$ & mRNA-1273 31$)$ & AZD122228) & Ad26.COV2. $\mathrm{S}^{30)}$ \\
\hline Manufacturer & Pfizer & Moderna & AstraZeneca & Janssen (J\&J) \\
\hline $\begin{array}{l}\text { Solicited adverse } \\
\text { events }\end{array}$ & $\begin{array}{l}\text { After 2nd dose: } \\
\text { 1) } 16-55 \text { yr } \\
\text { Fever: } 16 \% \\
\text { Fatigue: } 59 \% \\
\text { Headache } 52 \% \\
\text { Muscle pain: } 37.3 \% \\
\text { Joint pain: } 21.9 \% \\
\text { 2) Over } 55 \text { yr } \\
\text { Fever: } 11 \% \\
\text { Fatigue: } 51 \% \\
\text { Headache: } 39 \% \\
\text { Muscle pain: } 28.7 \% \\
\text { Joint pain: } 21.9 \%\end{array}$ & $\begin{array}{l}\text { After 2nd dose: } \\
\text { Fever: } 15.7 \% \\
\text { Headache: } 58.9 \% \\
\text { Fatigue: } 65.7 \% \\
\text { Myalgia: } 58.0 \% \\
\text { Arthralgia: } 42.9 \% \\
\text { Nausea/vomiting: } 19.0 \% \\
\text { Chills: } 44.4 \%\end{array}$ & $\begin{array}{l}\text { After } 2 \text { nd dose: } \\
\text { Feverish: } 51 \% \text {, } \\
\text { Fever }>38^{\circ} \mathrm{C}: 18 \%,>39^{\circ} \mathrm{C}: 2 \% \\
\text { Headache: } 68 \% \\
\text { Fatigue: } 70 \% \\
\text { Myalgia: } 60 \%\end{array}$ & $\begin{array}{l}\text { Fever: } 9.0 \% \\
\text { Fatigue: } 38.2 \% \\
\text { Headache: } 39.0 \% \\
\text { Myalgia: } 33.2 \%\end{array}$ \\
\hline $\begin{array}{l}\text { Serious adverse } \\
\text { event }\end{array}$ & $\begin{array}{l}\text { Vaccine related: } \\
\text { 1) Vaccine group ( } \mathrm{n}=4 \text { ): } \\
\text { (shoulder injury related to } \\
\text { vaccine administration, } \mathrm{n}=1 \text {; } \\
\text { right axillary Iymphadeno- } \\
\text { pathy, } \mathrm{n}=1 \text {; paroxysmal ven- } \\
\text { tricular arrhythmia, } \mathrm{n}=1 \text {; } \\
\text { right leg paresthesia, } \mathrm{n}=1 \text { ) } \\
\text { 2) Placebo group: } \mathrm{NA} \\
\text { Deaths during trial: } \\
\text { 1) Vaccine group, } \mathrm{n}=2 \text { (arterio- } \\
\text { sclerosis, } \mathrm{n}=1 \text {; cardiac arrest, } \\
\mathrm{n}=1 \text { ) } \\
\text { 2) Placebo group, } \mathrm{n}=4 \text { (un- } \\
\text { known cause, } \mathrm{n}=2 ; \text { hemorrha- } \\
\text { gic stroke, } \mathrm{n}=1 \text {; myocardial } \\
\text { infarction, } \mathrm{n}=1 \text { ). } \\
\text { a) No deaths related to the } \\
\text { vaccine or placebo }\end{array}$ & $\begin{array}{l}\text { Vaccine related: } \\
\text { 1) Vaccine group, } n=6(N A) \\
\text { 2) Placebo group, } n=4(N A) \\
\text { Deaths during trial: } \\
\text { 1) Vaccine group, } n=2 \text { (cardio- } \\
\text { pulmonary arrest, } n=1 \text {; } \\
\text { suicide, } n=1 \text { ) } \\
\text { 2) Placebo group, } n=3 \text { (intra- } \\
\text { abdominal perforation, } n=1 \text {; } \\
\text { cardiopulmonary arrest, } n= \\
\text { 1; severe systemic inflam- } \\
\text { matory syndrome, } n=1 \text { ) }\end{array}$ & $\begin{array}{l}\text { Vaccine related: } \\
\text { 1) Vaccine group, } n=2 \text { (Trans- } \\
\text { verse myelitis, } n=1 \text {, Pyrexia } \\
>40.0^{\circ} \mathrm{C}, \mathrm{n}=1 \text { ) } \\
\text { 2) Control group, } n=1 \text { (He- } \\
\text { molytic anemia, } n=1 \text { ) } \\
\text { Deaths during trial: } \\
\text { 1) Vaccine group, } n=1 \\
\text { 2) Control group, } n=3 \text { (all vac- } \\
\text { cine unrelated; road traffic } \\
\text { accident, blunt force trauma, } \\
\text { homicide, and fungal pneu- } \\
\text { monia) }\end{array}$ & $\begin{array}{l}\text { Vaccine related: } \\
\text { 1) Vaccine group, } n=7 \text { (Guillain- } \\
\text { Barre syndrome, } n=1 \text {; type IV } \\
\text { hypersensitivity, } n=1 \text {; Bell's } \\
\text { Palsy, } n=2 \text {; pericarditis, } n=1 \text {; } \\
\text { brachial radiculitis, } n=1 \text {; post- } \\
\text { vaccination syndrome, } n=1 \text { ) } \\
\text { 2) Placebo group, (DVT, } n=1 \text {, } \\
\text { EBV infection and atrial flut- } \\
\text { ter, } n=1 \text { ) } \\
\text { Deaths during trial: } \\
\text { 1) Vaccine group, } n=3 \text { (lung ab- } \\
\text { scess, non-COVID-19 pneu- } \\
\text { monia, unknown cause) } \\
\text { 2) Placebo group, } n=16 \text { (All } \\
\text { study unrelated) }\end{array}$ \\
\hline
\end{tabular}

NA, not available; DVT, deep vein thrombosis; EBV, Epstein-Barr virus.

a) AstraZeneca vaccine recipients were divided into 2 groups based on prophylactic paracetamol administration. The percentage are of patients not given paracetamol.

cases reported after an airplane flight (1 per 1,000). Therefore, the benefit of vaccination is considered to outweigh the risks. ${ }^{37-39)}$ The Korea Disease Control and Prevention Agency also reported that Koreans aged 30 years and older would be estimated to have a higher risk of potential death or severe infection from COVID-19 than the risk of death from thromboembolism, which is extremely rare after AZD1222 vaccination. Therefore, since April 12, 2021, AZD1222 vaccination was started again in the general population age of 30 and above in Korea (Fig. 3). ${ }^{40)}$ Ad26.COV2.S vaccination was also temporarily suspended in the US in order to assess the risks of thromboembolism related to the vaccine. However, on April 25, 2021, Ad26.COV2.S vaccination was resumed because benefits of Janssen COVID-19 vaccination among persons aged $\geq 18$ years outweighed the risks and reaffirmed the recommendation under FDA's EUA with including a new warning for rare clotting events among women aged $18-49$ years. ${ }^{41)}$

\section{COVID-19 vaccine in children and adolescents}

The ongoing and completed COVID-19 vaccine trials in children and adolescents are shown on Table 4. Currently, the
mRNA-1273, AZD1222, and Ad26.COV2.S vaccines have been approved for use in those aged 18 years and older. The clinical trial of the BNT162b2 vaccination in 2,200 children between the age of 12 and 15 was completed in January 2021. Pfizer-BioNTech reported in March 2021 that the vaccine efficacy was $100 \%$ leading to the FDA authorization for emergency use in adolescents 12 through 15 years of age as of May 10, 2021. Currently, Pfizer-BioNTech is recruiting children between the age of 6 months to 11 years for an ongoing phase 1/2/3 clinical study. ${ }^{42,43)}$ In February 2021, the clinical trial of the mRNA-1273 vaccination in 3,000 children aged 12-17 years was completed, and on February 13, 2021, the phase 2/3 clinical trial in children between the age of 6 months and 11 years was started (KidCove study). ${ }^{44,45)}$ The phase 2 clinical trial for AZD1222 in 300 children between the ages of 6-17 years old was started on February 13, 2021 but halted in April, and a clinical trial of Ad26.COV2.S in pediatric participants is being strategized. ${ }^{47)}$

As of 2020 , the population under 20 years old make up 33.3\% of the world's population, $24.8 \%$ of the US population, and $17.4 \%$ of the South Korean population. ${ }^{48)}$ Most COVID-19 cases in children and adolescents are asymptomatic and mild, and this raises the question of whether vaccinating children is 


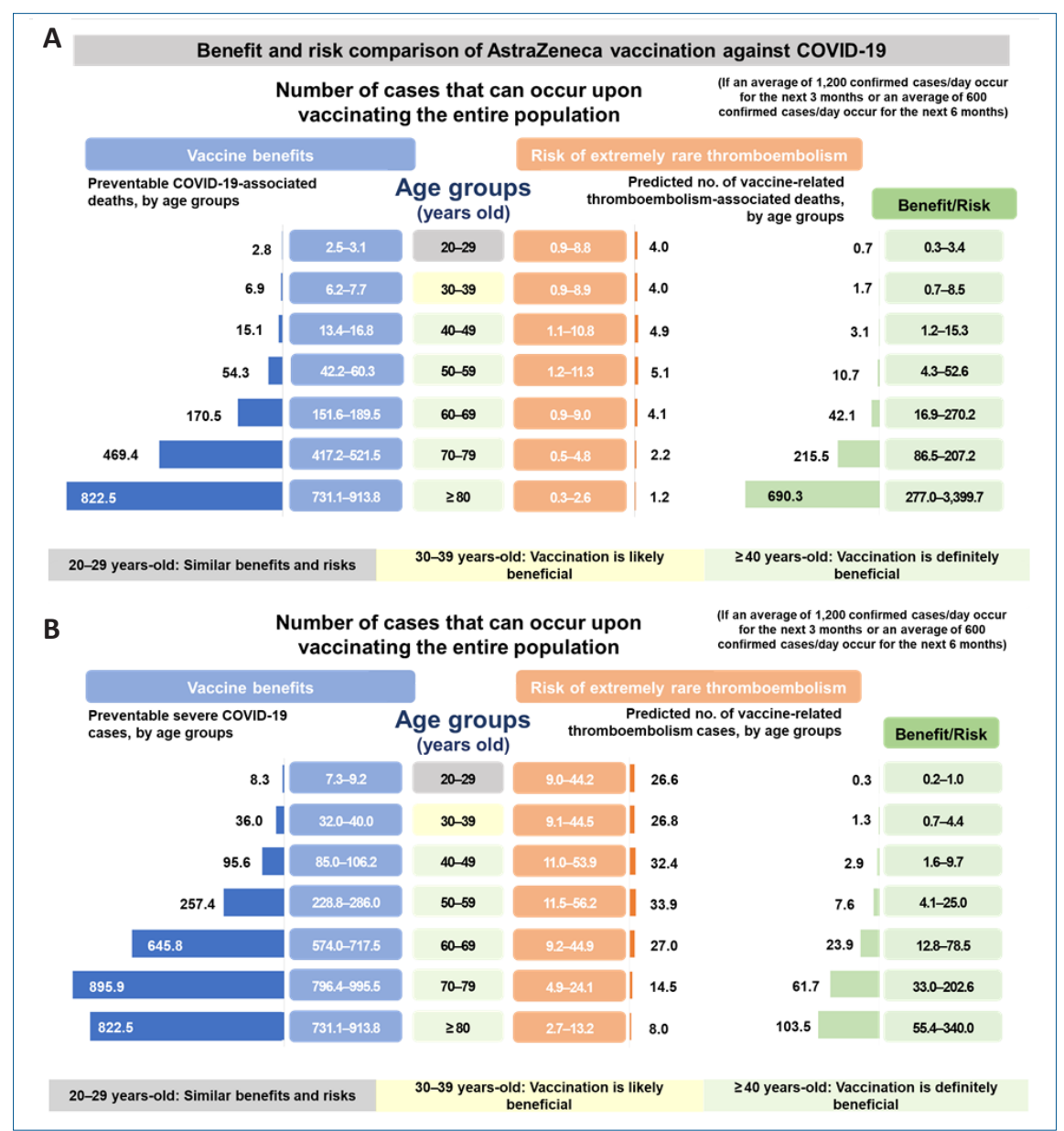

Fig. 3. The potential benefits and harms of the AstraZeneca vaccine in the prevention of COVID-19 related deaths (A) and serious illness (B). Modified from public health weekly report, PHWR, Vol. 14, No. 7, 2021.

Table 4. Ongoing clinical trials of coronavirus disease 2019 (COVID-19) vaccines on children

\begin{tabular}{|c|c|c|c|c|}
\hline & \multicolumn{4}{|c|}{ Vaccine name } \\
\hline & BNT162b2 $2^{42,43)}$ & $m R N A-1273^{44,45)}$ & AZD1222 ${ }^{46)}$ & Ad26.COV2. $S^{47)}$ \\
\hline Manufacturer & Pfizer & Moderna & AstraZeneca & Janssen (J\&J) \\
\hline $\begin{array}{l}\text { Ongoing/completed } \\
\text { clinical trials on children }\end{array}$ & $\begin{array}{l}\text { Phase 3: } \\
\text { - Adolescents 12-15 yr } \\
\text { Phase } 3 \text { (finished) summary: } \\
\mathrm{N}=2,260 \\
\text { Confirmed COVID-19 after } \\
\quad \text { last vaccination: } \\
\text { Vaccine group: } \mathrm{n}=18 / 1,129 \\
\text { Placebo group: } \mathrm{n}=0 / 1,131 \\
\text { Phase } 1 / 2 / 3(2021.3-\text { ): } \\
\text { recruiting } 6 \text { mo to } 11 \mathrm{yr}\end{array}$ & $\begin{array}{l}\text { Phase } 2 / 3 \text { (2021.2-): Recrui- } \\
\text { ting adolescents } 12-17 \mathrm{yr} \\
\text { Phase } 2 / 3 \text { (2021.3-): Recrui- } \\
\text { ting children } 6 \text { mo to } 11 \mathrm{yr}\end{array}$ & $\begin{array}{l}\text { Phase } 2 \text { (2021.02-): recruit- } \\
\text { ing children } \geq 6 \mathrm{yr}\end{array}$ & $\begin{array}{l}\text { Phase 2a: } \\
\text { - Plans to include newborns } \\
\text { and adolescents } \\
\text { - First, recruiting adolescents } \\
12-17 \text { yr }\end{array}$ \\
\hline
\end{tabular}

necessary. ${ }^{49-54)}$ There are certain expected benefits of vaccinating children with COVID-19 vaccines. Although rare, severe clinical courses of COVID-19 infections are observed in children and adolescents. Thus, severe diseases in high-risk children and adolescents can be prevented by inducing direct immunity to SARS-CoV-2. ${ }^{50)}$ The case fatality rate of COVID-19 infection is significantly lower in children and adolescents compared to that of adults. However, in the US, 279 pediatric patients died of COVID-19 infection between May 21, 2020 and March 25, $2021 .^{55)}$ In contrast, 188 pediatric patients died of influenza in
2019-2020 influenza season, suggesting that the burden of COVID-19 in pediatric population should not be ignored. ${ }^{56}$ Additionally, vaccines may prevent multisystem inflammatory syndrome in children, which is presumed to be associated with COVID-19. ${ }^{57)}$ The indirect benefit of vaccination is the formation of herd immunity. If only adults are vaccinated, COVID-19 outbreaks may continue in the population of unvaccinated children and adolescents. Because infections may spread from children and adolescents to the adults, restrictions on school and limitations on social activities of pediatric population 
may continue. Therefore, vaccinating children and adolescents may be necessary to effectively prevent the spread of COVID-19 infections. ${ }^{58-60)}$ In the US, with the ongoing COVID-19 vaccinations in adults together with schools reopening, the proportion of COVID-19 confirmed cases in children has increased from $13.6 \%$ to nearly $21 \% .{ }^{61)}$ Therefore, in Korea, after the vaccine rollout, careful monitoring of the proportion of children confirmed with COVID-19 is important. However, safety issues are continuously reported since the initiation of largescale vaccinations using new platform vaccines during the first half of 2021, and many countries and government agencies are still revising vaccination plans for adults. Additionally, there are currently no data on the long-term effects of these new platform vaccines. Therefore, careful approach must be taken in the decision for vaccinating children and adolescents. Because they are at a low risk for severe COVID-19, there is still debate on whether the benefits of the COVID-19 vaccine outweight the risks in this population. Therefore, it is absolutely necessary to obtain safety data prior to the decision of vaccinating children and adolescents.

\section{Conclusion}

The efficacy of the 4 COVID-19 vaccines authorized for emergency use is BNT162b2 95\% (95\% credible interval, $90.3-$ 97.6), mRNA-1273 94.1\% (95\% CI, 89.3-96.8), ADZ1222 70.4\% (95\% CI, 54.8-80.6), and Ad26.COV2.S 66.9\% (95\% CI, 59.1-73.4), suggesting that all these vaccines are efficacious. Clinical trials of these vaccines have shown that they are safe and that serious adverse reactions were rarely observed. The findings of the studies suggest that the benefits of the vaccines outweigh the risks. As COVID-19 vaccines have been authorized for use, real-world data on their effectiveness are continuously being reported with vaccine rollout in the communities. Safety data of the vaccines in adults are being accumulated, and additional data in children and adolescents are currently being generated. Therefore, it is necessary to continue following up on the ongoing updates on COVID-19 vaccines from countries around the world that have begun vaccinations.

\section{Conflicts of interest}

No potential conflict of interest relevant to this article was reported.

\section{Acknowledgments}

We would like to express our gratitude to Kyung-Ran Kim, Doo Ri Kim, Ye-Ji Kim, and Hwanhee Park for reviewing the data of the studies described in this manuscript.

\section{ORCID}

Hyun Mi Kang (1) https://orcid.org/0000-0003-0513-8407

Eun Hwa Choi 1 i https://orcid.org/0000-0002-5857-0749

Yae-Jean Kim 1 (1) https://orcid.org/0000-0002-8367-3424

\section{References}

1. Fraser C, Riley S, Anderson RM, Ferguson NM. Factors that make an infectious disease outbreak controllable. Proc Natl Acad Sci U S A 2004; 101:6146-51.

2. Peak CM, Childs LM, Grad YH, Buckee CO. Comparing nonpharmaceutical interventions for containing emerging epidemics. Proc Natl Acad SciUS A 2017;114:4023-8.

3. Weber DJ, Rutala WA, Fischer WA, Kanamori H, Sickbert-Bennett EE. Emerging infectious diseases: focus on infection control issues for novel coronaviruses (Severe Acute Respiratory Syndrome-CoV and Middle East Respiratory Syndrome-CoV), hemorrhagic fever viruses (Lassa and Ebola), and highly pathogenic avian influenza viruses, A(H5N1) and A(H7N9). Am J Infect Control 2016;44(5 Suppl):e91-100.

4. Park Y, Huh IS, Lee J, Kang CR, Cho SI, Ham HJ, et al. Application of testing-tracing-treatment strategy in response to the COVID-19 outbreak in Seoul, Korea. J Korean Med Sci 2020;35:e396.

5. Haber MJ, Shay DK, Davis XM, Patel R, Jin X, Weintraub E, et al. Effectiveness of interventions to reduce contact rates during a simulated influenza pandemic. Emerg Infect Dis 2007;13:581-9.

6. World Health Organization. Draft landscape and tracker of COVID-19 candidate vaccines [Internet]. Geneva (Switzerland): World Health Organization; 2021 [cited 2021 Mar 12]. Available from: https:/www.who. int/publications/m/item/draft-landscape-of-covid-19-candidate-vaccines.

7. Lu R, Zhao X, Li J, Niu P, Yang B, Wu H, et al. Genomic characterisation and epidemiology of 2019 novel coronavirus: implications for virus origins and receptor binding. Lancet 2020;395:565-74.

8. Naqvi AAT, Fatima K, Mohammad T, Fatima U, Singh IK, Singh A, et al. Insights into SARS-CoV-2 genome, structure, evolution, pathogenesis and therapies: structural genomics approach. Biochim Biophys Acta Mol Basis Dis 2020;1866:165878.

9. Walls AC, Park YJ, Tortorici MA, Wall A, McGuire AT, Veesler D. Structure, function, and antigenicity of the SARS-CoV-2 spike glycoprotein. Cell 2020;181:281-92.e6.

10. Sternberg A, Naujokat C. Structural features of coronavirus SARS-CoV-2 spike protein: targets for vaccination. Life Sci 2020;257:118056.

11. Huang Y, Yang C, Xu XF, Xu W, Liu SW. Structural and functional properties of SARS-CoV-2 spike protein: potential antivirus drug development for COVID-19. Acta Pharmacol Sin 2020;41:1141-9.

12. Tian X, Li C, Huang A, Xia S, Lu S, Shi Z, et al. Potent binding of 2019 novel coronavirus spike protein by a SARS coronavirus-specific human monoclonal antibody. Emerg Microbes Infect 2020;9:382-5.

13. Walsh EE, Frenck RW Jr, Falsey AR, Kitchin N, Absalon J, Gurtman A, et al. Safety and immunogenicity of two RNA-Based Covid-19 vaccine candidates. NEngl J Med 2020;383:2439-50.

14. Jackson LA, Anderson EJ, Rouphael NG, Roberts PC, Makhene M, Coler $\mathrm{RN}$, et al. An mRNA vaccine against SARS-CoV-2 - preliminary report. $\mathrm{N}$ Engl J Med 2020;383:1920-31.

15. Folegatti PM, Ewer KJ, Aley PK, Angus B, Becker S, Belij-Rammerstorfer $\mathrm{S}$, et al. Safety and immunogenicity of the ChAdOx1 nCoV-19 vaccine against SARS-CoV-2: a preliminary report of a phase $1 / 2$, single-blind, randomised controlled trial. Lancet 2020;396:467-78.

16. Sadoff J, Le Gars M, Shukarev G, Heerwegh D, Truyers C, de Groot AM, et al. Interim results of a phase 1-2a Trial of Ad26.COV2.S Covid-19 vaccine. NEngl J Med 2021;384:1824-35.

17. World Health Organization. Status of COVID-19 vaccines within WHO EUL/PQ evaluation process [Internet]. Geneva (Switzerland): World Health Organization; 2021 [cited 2021 Mar 12]. Available from: https:// extranet.who.int/pqweb/sites/default/files/documents/Status_COVID_ VAX_10March2021.pdf.

18. Humphreys IR, Sebastian S. Novel viral vectors in infectious diseases. Immunology 2018;153:1-9.

19. Dai L, Gao GF. Viral targets for vaccines against COVID-19. Nat Rev Immunol 2021;21:73-82.

20. Krammer F. SARS-CoV-2 vaccines in development. Nature 2020;586: 516-27. 
21. Pichichero ME. Understanding messenger RNA and other SARS-CoV-2 vaccines [Internet]. Parsippany (NJ): Frontline Medical Communications Inc.; 2020 [cited 2021 Mar 12]. Available from: https://www.mdedge. com/hematology-oncology/article/233491/coronavirus-updates/ understanding-messenger-rna-and-other-sars.

22. Corbett KS, Edwards DK, Leist SR, Abiona OM, Boyoglu-Barnum $\mathrm{S}$, Gillespie RA, et al. SARS-CoV-2 mRNA vaccine design enabled by prototype pathogen preparedness. Nature 2020;586:567-71.

23. Corbett KS, Flynn B, Foulds KE, Francica JR, Boyoglu-Barnum S, Werner AP, et al. Evaluation of the mRNA-1273 vaccine against SARS-CoV-2 in nonhuman primates. NEngl J Med 2020;383:1544-55.

24. Antrobus RD, Coughlan L, Berthoud TK, Dicks MD, Hill AV, Lambe $\mathrm{T}$, et al. Clinical assessment of a novel recombinant simian adenovirus ChAdOx1 as a vectored vaccine expressing conserved influenza A antigens. Mol Ther 2014;22:668-74.

25. Zhang C, Zhou D. Adenoviral vector-based strategies against infectious disease and cancer. Hum Vaccin Immunother 2016;12:2064-74.

26. Afrough S, Rhodes S, Evans T, White R, Benest J. Immunologic doseresponse to adenovirus-vectored vaccines in animals and humans: a systematic review of dose-response studies of replication incompetent adenoviral vaccine vectors when given via an intramuscular or subcutaneous route. Vaccines (Basel) 2020;8:131.

27. Polack FP, Thomas SJ, Kitchin N, Absalon J, Gurtman A, Lockhart S, et al. Safety and efficacy of the BNT162b2 mRNA Covid-19 vaccine. N Engl J Med 2020;383:2603-15.

28. Baden LR, El Sahly HM, Essink B, Kotloff K, Frey S, Novak R, et al. Efficacy and safety of the mRNA-1273 SARS-CoV-2 vaccine. N Engl J Med 2021;384:403-16.

29. Voysey M, Clemens SAC, Madhi SA, Weckx LY, Folegatti PM, Aley PK, et al. Safety and efficacy of the ChAdOx1 nCoV-19 vaccine (AZD1222) against SARS-CoV-2: an interim analysis of four randomised controlled trials in Brazil, South Africa, and the UK. Lancet 2021;397:99-111.

30. Voysey M, Costa Clemens SA, Madhi SA, Weckx LY, Folegatti PM, Aley PK, et al. Single-dose administration and the influence of the timing of the booster dose on immunogenicity and efficacy of ChAdOx $1 \mathrm{nCoV}-19$ (AZD1222) vaccine: a pooled analysis of four randomised trials. Lancet 2021;397:881-91.

31. Sadoff J, Gray G, Vandebosch A, Cárdenas V, Shukarev G, Grinsztejn $\mathrm{B}$, et al. Safety and efficacy of single-dose Ad26.COV2.S vaccine against Covid-19. NEngl J Med 2021;384:2187-201.

32. U.S. Food and Drug Administration. Vaccines and Related Biological Products Advisory Committee. COVID-19 vaccine Ad26.COV2.S. Sponsor Briefing Document [Internet]. Silver Spring (MD): U.S. Food and Drug Administration; 2021 [cited 2021 Feb 21]. Available from: https://www.fda.gov/media/146219/download.

33. Muir KL, Kallam A, Koepsell SA, Gundabolu K. Thrombotic thrombocytopenia after Ad26.COV2.S vaccination. N Engl J Med 2021;384: 1964-5.

34. Schultz NH, Sørvoll IH, Michelsen AE, Munthe LA, Lund-Johansen F, Ahlen MT, et al. Thrombosis and thrombocytopenia after ChAdOx1 nCoV-19 vaccination. N Engl J Med 2021;384:2124-30.

35. Greinacher A, Thiele T, Warkentin TE, Weisser K, Kyrle PA, Eichinger S. Thrombotic thrombocytopenia after ChAdOx1 nCov-19 vaccination. $\mathrm{N}$ Engl J Med 2021;384:2092-101.

36. European Medicines Agency. AstraZeneca's COVID-19 vaccine: EMA finds possible link to very rare cases of unusual blood clots with low blood platelets [Internet]. Amsterdam (Netherlands): European Medicines Agency; 2021 [cited 2021 Mar 20]. Available from: https:/www.ema. europa.eu/en/news/astrazenecas-covid-19-vaccine-ema-finds-possiblelink-very-rare-cases-unusual-blood-clots-low-blood.

37. European Medicines Agency. COVID-19 Vaccine AstraZeneca: PRAC investigating cases of thromboembolic events - vaccine's benefits currently still outweigh risks - Update [Internet]. Amsterdam (Netherlands): European Medicines Agency; 2021 [cited 2021 Apr 1]. Available from: https://www.ema.europa.eu/en/news/covid-19-vaccine-astrazeneca-pracinvestigating-cases-thromboembolic-events-vaccines-benefits.

38. Østergaard SD, Schmidt M, Horváth-Puhó E, Thomsen RW, Sørensen
HT. Thromboembolism and the Oxford-AstraZeneca COVID-19 vaccine: side-effect or coincidence? Lancet 2021;397:1441-3.

39. Mahase E. AstraZeneca vaccine: blood clots are "extremely rare" and benefits outweigh risks, regulators conclude. BMJ 2021;373:n931.

40. Korea Disease Control and Prevention Agency. Recommencement of the AstraZeneca vaccine that was placed on hold, starting April 12 [Internet]. Cheongju (Korea): Korea Disease Control and Prevention Agency; 2021 [cited 2021 Apr 27]. Available from: http://www.kdca.go.kr/gallery. es? $\mathrm{mid}=\mathrm{a} 20503030300 \& \mathrm{bid}=0004 \& \mathrm{~b}$ list $=9 \& \mathrm{act}=$ view\&list no $=145062 \&$ nPage $=1 \&$ vlist_no_npage $=1 \&$ keyField $=\&$ keyWord $=$ \&orderby $=$.

41. Centers for Disease Control and Prevention. J\&J/Janssen update [Internet]. Atlanta (GA): Centers for Disease Control and Prevention; 2021 [cited 2021 Apr 27]. Available from: https://www.cdc.gov/coronavirus/2019ncov/vaccines/safety/JJUpdate.html.

42. U.S. Food and Drug Administration. Coronavirus (COVID-19) update: FDA authorizes Pfizer-BioNTech COVID-19 vaccine for emergency use in adolescents in another important action in fight against pandemic [Internet]. Silver Spring (MD): U.S. Food and Drug Administration; 2021 [cited 2021 Feb 21]. Available from: https:/www.fda.gov/news-events/ press-announcements/coronavirus-covid-19-update-fda-authorizes-pfizerbiontech-covid-19-vaccine-emergency-use.

43. Pfizer. Pfizer-BioNTech announce positive topline results of pivotal COVID-19 vaccine study in adolescents [Internet]. New York: Pfizer; 2021 [cited 2021 Mar 31]. Available from: https://www.pfizer.com/news/ press-release/press-release-detail/pfizer-biontech-announce-positivetopline-results-pivotal.

44. Moderna. Kidcove Study Trial ID: NCT04796896 [nternet]. Cambridge (MA): Moderna; 2021 [cited 2021 Mar 31]. Available from: https://connect. trialscope.com/studies/0e8fc8e6-5782-46fd-8b03-0994a5ad8b41.

45. ModernaTX Inc. A study to evaluate safety and effectiveness of mRNA1273 vaccine in healthy children between 6 months of age and less than 12 years of age [Internet]. Cambridge (MA): Moderna; 2021 [cited 2021 Mar 31]. Available from: https://clinicaltrials.gov/ct2/show/NCT04796 896.

46. National Institute for Health Research. First children's COVID-19 vaccine trial open [Internet]. London: National Institute for Health Research; 2021 [cited 2021 Mar 31]. Available from: https://www.nihr. ac.uk/news/first-childrens-covid-19-vaccine-trial-open/26870.

47. Johnson \& Johnson. Johnson \& Johnson expands phase 2a clinical trial of COVID-19 vaccine candidate to include adolescents [Internet]. New Brunswick (NJ): Johnson \& Johnson; 2021 [cited 2021 Apr 27]. Available from: https://www.jnj.com/johnson-johnson-expands-phase2a-clinical-trial-of-covid-19-vaccine-candidate-to-include-adolescents.

48. United Nations. Population Division (2019). World Population Prospects 2019, custom data acquired via website [Internet]. New York: United Nations; 2021 [cited 2021 Apr 14]. Available from: https://population. un.org/wpp/DataQuery/.

49. Lu X, Zhang L, Du H, Zhang J, Li YY, Qu J, et al. SARS-CoV-2 infection in children. NEngl J Med 2020;382:1663-5.

50. Han MS, Choi EH, Chang SH, Jin BL, Lee EJ, Kim BN, et al. Clinical characteristics and viral RNA detection in children with coronavirus disease 2019 in the Republic of Korea. JAMA Pediatr 2021;175:73-80.

51. Jiehao C, Jin X, Daojiong L, Zhi Y, Lei X, Zhenghai Q, et al. A case series of children with 2019 novel coronavirus infection: clinical and epidemiological features. Clin Infect Dis 2020;71:1547-51.

52. Liu W, Zhang Q, Chen J, Xiang R, Song H, Shu S, et al. Detection of Covid-19 in children in early January 2020 in Wuhan, China. N Engl J Med 2020;382:1370-1.

53. Qiu H, Wu J, Hong L, Luo Y, Song Q, Chen D. Clinical and epidemiological features of 36 children with coronavirus disease 2019 (COVID-19) in Zhejiang, China: an observational cohort study. Lancet Infect Dis 2020;20:689-96.

54. Choi SH, Kim HW, Kang JM, Kim DH, Cho EY. Epidemiology and clinical features of coronavirus disease 2019 in children. Clin Exp Pediatr 2020;63:125-32.

55. American Academy of Pediatrics. Children and COVID-19: state-level 
data report [Internet]. Itasca (IL): American Academy of Pediatrics; 2021 [cited 2021 Apr 2]. Available from: https://services.aap.org/en/ pages/2019-novel-coronavirus-covid-19-infections/children-and-covid19-state-level-data-report/.

56. Centers for Disease Control and Prevention. 2019-20 Season's pediatric flu deaths tie high mark set during 2017-18 season [Internet]. Atlanta (GA): Centers for Disease Control and Prevention; 2021 [cited 2021 Mar 4]. Available from: https://www.cdc.gov/flu/spotlights/2019-2020/201920-pediatric-flu-deaths.htm\#: :text=LinkedIn-,2019\%2D20\%20 Season's\%20Pediatric\%20Flu\%20Deaths $\% 20$ Tie $\% 20$ High,Set $\% 20$ During\%202017\%2D18\%20Season\&text $=$ August $\% 2021 \% 2 \mathrm{C} \% 20$ $2020 \% 20 \%$ E2\%80\%93\%20CDC\%20today,for $\% 20$ last $\% 20$ season $\%$ 20 to $\% 20188$.

57. Goodman B. Children likely the 'leading edge' in spread of COVID-19 variants [Internet]. New York: Medscape LLC; 2021 [cited 2021 Mar 31]. Available from: https://www.medscape.com/viewarticle/948584.

58. Klass P, Ratner AJ. Vaccinating Children against Covid-19 - The Lessons of Measles. NEngl J Med 2021;384:589-91.
59. Anderson EJ, Campbell JD, Creech CB, Frenck R, Kamidani S, Munoz FM, et al. Warp Speed for COVID-19 Vaccines: Why are Children Stuck in Neutral? Clin Infect Dis 2020 Sep 18; ciaa1425. https://doi.org/10.1093/ cid/ciaa1425. Epub.

60. Wong BLH, Ramsay ME, Ladhani SN. Should children be vaccinated against COVID-19 now? Arch Dis Child 2021 Jan 5:archdischild-2020321225. https://doi.org/10.1136/archdischild-2020-321225. Epub.

61. AAP News and Journals. Children make up nearly 21\% of new COVID-19 cases [Internet]. Itasca (IL): American Academy of Pediatrics; 2021 [cited 2021 May 28]. Available from: https://www.aappublications. org/news/2021/04/19/pediatric-covid-cases-041921.

How to cite this article: Kang HM, Choi EH, Kim YJ. Updates on the coronavirus disease 2019 vaccine and consideration in children. Clin Exp Pediatr 2019;64:328-38. https://doi.org/ 10.3345/cep.2021.00696 